Caine DJ, Maffulli N (eds): Epidemiology of Pediatric Sports Injuries.

Individual Sports. Med Sport Sci. Basel, Karger, 2005, vol 48, pp 152-178

\title{
Wrestling Injuries
}

\author{
Timothy E. Hewett ${ }^{\mathrm{a}, \mathrm{b}}$, Charles Pasque \\ Rachel Heyl ${ }^{\mathrm{a}}$, Randy Wroble ${ }^{\mathrm{d}}$ \\ ${ }^{a}$ Cincinnati Children's Hospital Research Foundation, Cincinnati Children's \\ Medical Hospital Center Sports Medicine Biodynamics Center, bUniversity of \\ Cincinnati College of Medicine, and Departments of Pediatrics, Orthopaedic \\ Surgery and Rehabilitation Sciences, 'University of Oklahoma Medical Center, \\ ${ }^{\mathrm{d} S p o r t s m e d i c i n e ~ G r a n t, ~ C o l u m b u s, ~ O h i o, ~ U S A ~}$
}

\begin{abstract}
Objective: The purpose of this chapter is to review critically the existing studies on the epidemiology of pediatric wrestling injuries and to discuss suggestions for injury prevention and further research. Data sources: Data were obtained from the sports medicine and science literature since 1951. Literature searches were performed using the National Library of Medicine, Pubmed, Medline, Grateful Med, Sports Sciences, SportsDiscus. Keywords used included 'Wrestling, Wrestle, Wrestling Injuries, Fractures, and Dermatologic'. Main results: Only eight prospective or retrospective studies were found dealing with pediatric wrestling injuries and that provided sufficient information to allow the estimation of injury rates. Exposure-based injury rates were between 6.0 and 7.6 injuries per 1,000 athletic-exposures. Injury rates increased with age, experience, and level of participation. The head/spine/trunk was the body region that incurred the greatest frequency of injuries, followed by the upper and lower extremities. Conclusions: There are several potential areas for decreasing injury risk in wrestlers, including equipment, coaching, officiating and training. However, informed decisions with regard to preventing injuries are dependent upon the quality of the basic epidemiological data available, and at this time, analyses of risk factors and potential preventive measures are lacking.
\end{abstract}

Copyright (C) 2005 S. Karger AG, Basel

\section{Introduction}

This chapter is a review of the epidemiological literature on wrestling injuries in the pediatric population. Due to the relative lack of information on pediatric wrestling injuries, a broad search was performed that included all 
studies on the epidemiology of wrestling injuries, focusing especially on the high school level. Case studies were included in some sections in order to fill the gaps left by a lack of pediatric wrestling studies. As with many other areas of sports injury research, it is difficult to compare the findings of different studies because the study designs, injury definition, and population studied are so varied.

A search of the National Library of Medicine Pubmed, Medline, Grateful Med, Sports Sciences, Sports Discus, was conducted from 1951 to present under 'wrestling' and 'injuries'. This search yielded most of the articles used in this review. We also searched under 'fractures in wrestling', and 'dermatologic conditions in wrestling'. The most useful articles were all found using the keywords 'wrestling injuries'. We also used references from some of the articles found from the literature search.

\section{Incidence of Injury}

A summary of studies reporting on the incidence of pediatric wrestling injuries is shown in table 1 [1-8]. A review of this table reveals that it is difficult to compare incidence of injury across studies because of the variety of ways in which 'injury' has been defined and the differing ways in which rates have been calculated. Kersey and Rowan [9] defined an injury as any incident in which an official halted a match. With such a liberal definition, the likelihood of overreporting is high, where a bloody nose or stalling tactics by a wrestler may be included as data. Strauss and Lanese [8] recorded only those injuries that reached the athletic training room. This leaves the potential for many minor injuries to be under-reported. There was a little more consistency in defining injury between studies done by Lorish et al. [5] and Pasque and Hewett [7]. In these cases, the definition of injury usually involved: (1) limitation of function to an extent that the athlete sought treatment by an athletic trainer or physician; (2) restricted participation of at least one day beyond the initial injury.

Pasque and Hewett [7] prospectively examined injury patterns of high school athletes over one 3-month season. The overall injury rate at the end of the season was 6.0/1,000 athlete-exposures. Similarly, Hoffman [3] reported a rate of 7.6 injuries per 1,000 athletic-exposures in high school wrestlers followed over two seasons.

Only two studies examined injury rates in school-age wrestlers exclusively. Lorish et al. [5] reported on injury patterns occurring during the course of two wrestling tournaments involving athletes between the ages of 6 and 16 . When comparing risk of injury and severity of injury between preadolescent and adolescent boys, older boys were at significantly greater risk for injury. Strauss and Lanese [8] also reported on injuries at a wrestling tournament. 
Table 1. Epidemiological study summary

\begin{tabular}{|c|c|c|c|c|c|c|}
\hline Author & Study design & $\begin{array}{l}\text { Collection } \\
\text { methods }\end{array}$ & $\begin{array}{l}\text { Study } \\
\text { duration }\end{array}$ & $\begin{array}{l}\text { Number of } \\
\text { participants }\end{array}$ & $\begin{array}{l}\text { Number of } \\
\text { injuries }\end{array}$ & Injury rates \\
\hline $\begin{array}{l}\text { Bailes et al. } \\
\text { [1] }\end{array}$ & $\begin{array}{l}\mathrm{R} ; \mathrm{HS} \text { and } \mathrm{C} \text {; cervical } \\
\text { spine and cord }\end{array}$ & $\mathrm{D}$ & 12 years & 63 athletes & $\begin{array}{l}\text { 13/63 injured } \\
\text { wrestlers }\end{array}$ & \\
\hline $\begin{array}{l}\text { Boden et al. } \\
{[2]}\end{array}$ & $\begin{array}{l}\mathrm{R} ; \mathrm{HS} \text { and } \mathrm{C} ; \\
\text { catastrophic injuries }\end{array}$ & $\mathrm{D}, \mathrm{I}, \mathrm{Q}$ & 18 years & $\begin{array}{l}\mathrm{HS}=4,041,486 \\
\mathrm{C}=129,858\end{array}$ & $\begin{array}{l}54 \text { catastrophic } \\
\text { injuries }\end{array}$ & $\begin{array}{l}2.11 \text { catastrophic } \\
\text { injury/year, } \\
\mathrm{HS}=0.00084 \% \\
\mathrm{C}=0.0007 \%\end{array}$ \\
\hline $\begin{array}{l}\text { Hoffman and } \\
\text { Powell [3] }\end{array}$ & $\mathrm{P} ; \mathrm{HS}$ & $\mathrm{D}, \mathrm{I}$ & 2 seasons & 159,470 A-E & not given & 7.6/1000 A-E \\
\hline $\begin{array}{l}\text { Kvitten et al. } \\
{[4]}\end{array}$ & $\begin{array}{l}\text { P; HS; orofacial } \\
\text { injuries }\end{array}$ & $\mathrm{I}, \mathrm{Q}$ & 1 season & 101 & 73 & $\begin{array}{l}69.9 \% \text { of wrestlers } \\
\text { sustained at least one } \\
\text { injury }\end{array}$ \\
\hline $\begin{array}{l}\text { Lorish et al. } \\
\text { [5] }\end{array}$ & $\begin{array}{l}\text { likely P; grade } \\
\text { school, HS }\end{array}$ & $\mathrm{I}, \mathrm{Q}$ & $\begin{array}{l}1 \text { season } \\
\text { ( } 2 \text { tournaments) }\end{array}$ & 1,742 & 221 & $12.70 \%$ \\
\hline $\begin{array}{l}\text { Mueller and } \\
\text { Cantu [6] }\end{array}$ & $\begin{array}{l}\text { likely R; HS, C; } \\
\text { catastrophic injuries }\end{array}$ & I, Q & 6 years & $\begin{array}{l}\mathrm{HS}=250,000 \\
\mathrm{C}=8,000\end{array}$ & $\begin{array}{l}\mathrm{HS}=23 \\
\mathrm{C}=0\end{array}$ & no rates given \\
\hline $\begin{array}{l}\text { Pasque and } \\
\text { Hewett [7] }\end{array}$ & $\mathrm{P} ; \mathrm{HS}$ & $\mathrm{I}, \mathrm{Q}$ & 1 season & $\begin{array}{l}418 \\
36,473 \text { A-E }\end{array}$ & 219 & $\begin{array}{l}52 / 100 \text { wrestlers/ } \\
\text { season } \\
6.0 / 1,000 \text { A-E }\end{array}$ \\
\hline $\begin{array}{l}\text { Strauss and } \\
\text { Lanese [8] }\end{array}$ & $\begin{array}{l}\text { P; grade school, } \\
\text { HS, C }\end{array}$ & I & $\begin{array}{l}1 \text { season } \\
\text { (4 tournaments) }\end{array}$ & $\begin{array}{l}1,049 \text { total } \\
291 \text { boys } \\
758 \text { HS and C }\end{array}$ & $\begin{array}{l}11 \text { boys } \\
91 \text { HS and C }\end{array}$ & $\begin{array}{l}3.78 \text { injuries } / 100 \\
\text { wrestlers (HS, C) } \\
12.0 / 100 \text { athletes (HS, C) }\end{array}$ \\
\hline
\end{tabular}


Amongst boys, the rate of injury was 3.78 injuries per 100 participants, compared to high school and college injury rates of 12.0 per 100 participants.

\section{Injury Characteristics}

\section{Injury Onset}

Although overuse injuries can and do occur in wrestling, they are few in number relative to the acute injuries, which tend to be the ones reported in the studies reviewed. Pasque and Hewett [7] specifically stated that any injury that was an aggravation of a previous injury or was a reinjury was not recorded as a new injury in their study. However, the study later reported that $6 \%$ of the athletes injured in the preseason suffered a reaggravation of that injury during the regular season. Strauss and Lanese [8] included reinjury and new injury in incidence rates, and reported that aggravation of old injuries accounted for $39 \%$ of all injuries reported. Mysnyk et al. [10] looked specifically at the incidence of prepatellar bursitis and reported that 8 of 13 athletes suffering from this condition had at least one recurrence.

\section{Injury Location}

A breakdown of the epidemiological data by location of injury is seen in table $2[5,7,8,11-17]$. Review of this table reveals that the body region incurring the greatest percentage of injuries is the head/spine/trunk (range of 24.5-48\%) followed by the upper extremity (range of 9.3-42\%). The next highest is the lower extremity (range of 7.5-45.1\%) and lastly the skin (range of 5-21.6\%).

\section{Head Injury}

Concussions and other head injuries have occurred from $1-8 \%$ of all wrestling injuries $[5,7,11]$. Bruce et al. [18] documented the low incidence of major head and spine trauma in children, but showed an increase in the 15- to 18-year-old age group. Powell and Barber-Foss [14], in a 3-year high school study, found that concussions occur more frequently in matches and that takedowns were the most high-risk situation for concussion.

Ocular trauma rates are very low in the epidemiological studies shown in table 2. Forrest et al. [19] reported 2 cases of orbital blowout fractures in wrestlers. One case was from an elbow to the eye, the other from a knee to the eye.

Lee-Knight et al. [20] reviewed dental injuries at the Canada games. In this 7-day freestyle competition, 101 wrestlers aged 14-21 sustained only one dental injury. Persson and Kiliaridis [21] compared the incidence of dental and temporomandibular injuries in a group of 26 wrestlers to a matched group of controls. They found that wrestlers had more frequent severe injuries located to the 


\begin{tabular}{|c|c|c|c|c|c|c|c|c|c|c|c|}
\hline Study & $\begin{array}{l}\text { Konrad } \\
{[12]}\end{array}$ & $\begin{array}{l}\text { Patacsil } \\
\text { [11], HS }\end{array}$ & $\begin{array}{l}\text { Lorish } \\
\text { et al. [5] }\end{array}$ & $\begin{array}{l}\text { Strauss and } \\
\text { Lanesse [8] }\end{array}$ & $\begin{array}{l}\text { Requa and } \\
\text { Garrick [13] }\end{array}$ & $\begin{array}{l}\text { Powell and } \\
\text { Barber-Foss } \\
{[14]}\end{array}$ & $\begin{array}{l}\text { Pasque and } \\
\text { Hewett [7] }\end{array}$ & $\begin{array}{l}\text { Lok and } \\
\text { Yuceturk } \\
{[15]}\end{array}$ & $\begin{array}{l}\text { Estwanik } \\
\text { et al. [16] }\end{array}$ & $\begin{array}{l}\text { Acksel } \\
{[17]}\end{array}$ & Range \\
\hline $\begin{array}{l}\text { Study } \\
\text { design }\end{array}$ & $\mathrm{P}$ & $\mathrm{P}$ & $\mathrm{P}$ & $\mathrm{P}$ & $\mathrm{P}$ & $\mathrm{P}$ & $\mathrm{P}$ & $\mathrm{R}$ & $\mathrm{R}$ & $\mathrm{R}$ & \\
\hline Skin & 21.6 & & 6.8 & & & & 5 & & & & 5-21.6 \\
\hline $\begin{array}{l}\text { Head/Spine/ } \\
\text { Trunk }\end{array}$ & 39.5 & 47.2 & 43.9 & 48 & 37.5 & 28.4 & 27 & 25.7 & 24.5 & 45.35 & $24.5-48$ \\
\hline Head & & 1.2 & 6.3 & & 3.6 & & 8 & & & 3.8 & $1.2-8$ \\
\hline Face/Mouth & & 2.5 & 2.3 & & & & & & & 1 & $1.0-2.5$ \\
\hline Ear & 23.4 & 16.2 & 0.9 & & & & & & 7.6 & 17.3 & $0.9-23.4$ \\
\hline Nose & 1.2 & 2.5 & 1.8 & & & & & 3.2 & 5.7 & 0.7 & $0.7-5.7$ \\
\hline Eye & & 3.7 & 4.1 & & & & & & & & $3.7-4.1$ \\
\hline Teeth & & 2.5 & & & & & & & & 2.1 & $2.1-2.5$ \\
\hline Neck & 3.6 & 8.7 & 14.9 & & & & & 6.4 & & 3.5 & $3.5-14.9$ \\
\hline Upper back & & 2.5 & 1.4 & & & & & & & & $1.4-2.5$ \\
\hline Lower back & 4.7 & 1.2 & 7.7 & 18.6 & & & & & 6.2 & 8.3 & $1.2-18.6$ \\
\hline Rib/Chest & 6.6 & 6.2 & 4.1 & & & & & 16.1 & 5 & 8.3 & $4.1-16.1$ \\
\hline Abdomen & & & 0.4 & & & & & & & 0.35 & $0.35-0.4$ \\
\hline Upper extremity & 9.3 & 22.4 & 33 & 20.6 & 29.1 & 32.6 & 42 & 29 & 26.2 & 32.8 & $9.3-42$ \\
\hline Shoulder & 3.5 & 7.5 & 16.7 & & & & 24 & 22.6 & 16.2 & 10.7 & $3.5-24$ \\
\hline Arm & 0.8 & & 1.4 & & & & & & & 1.4 & $0.8-1.4$ \\
\hline Elbow & 1 & 3.7 & 3.6 & & & & 7 & 3.2 & 5 & 7.9 & $1.0-7.9$ \\
\hline Wrist & 2.8 & & 2.7 & & & & & 3.2 & & 4.8 & $2.7-4.8$ \\
\hline Forearm & & & & & & & & & & & \\
\hline Hand/Finger & 1.2 & 11.2 & 8.6 & & 5.9 & & & & 5 & 8.6 & $1.2-11.2$ \\
\hline Lower extremity & 7.5 & 29.9 & 15.4 & 31.4 & 33.3 & 27.2 & 31 & 45.1 & 42.3 & 24.45 & $7.5-45.1$ \\
\hline Pelvis/Hip & & 2.5 & 1.8 & & & & & 3.2 & & 2.1 & $1.8-3.2$ \\
\hline Thigh & & 2.5 & & & 1.2 & & & 3.2 & & 0 & $0-3.2$ \\
\hline Knee & 1.2 & 13.7 & 7.7 & & 19.6 & 14.8 & 17 & 29 & 38.4 & 9.3 & $1.2-38.4$ \\
\hline
\end{tabular}




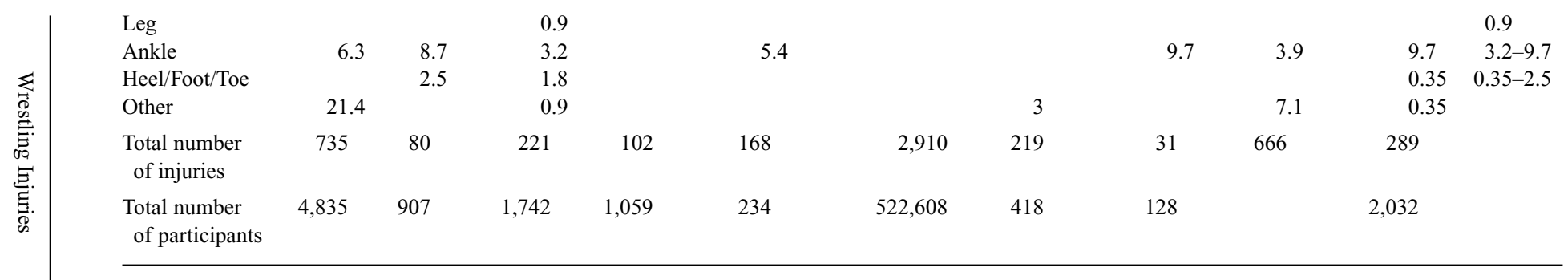

$\mathrm{P}=$ Prospective $; \mathrm{R}=$ retrospective. 
frontal region of the maxilla than controls, but found no increased incidence of temporomandibular joint disorders or dental caries.

Kvittem et al. [4] reviewed orofacial injuries at seven high schools during one school year. They found that $69.9 \%$ of wrestlers sustained some type of orofacial injury. Most of these were lacerations and contusions. Dental injuries in this study accounted for $10 \%$ of the overall total.

One of the classic injuries of wrestling is acute or recurrent auricular hematomas resulting in 'cauliflower ear' or 'wrestler's ear'. Although it is possible to incur these injuries while wearing headgear, most occur when the wrestler is not wearing headgear. In an early study of high school wrestlers, only two of forty-nine coaches $(4.1 \%)$ required their wrestlers to wear headgear [18]. In the few studies which have documented ear injuries, these have comprised from 1.7 to $24.6 \%$ of the total number of wrestling injuries.

Data on injuries occurring to the nasal region have been collected in several studies [5, 11-17]. As table 2 reveals, these injuries range from $0.7 \%$ as reported by Acksel [17] to 5.7\% of total injuries recorded by Estwanik et al. [16].

Neck Injury

In a variety of prospective and retrospective epidemiological studies of wrestling injuries, neck injuries were $0.8-14.9 \%$ of the total number of injuries $[5,11,12,15,17,22]$.

A cervical strain is a tear of one of the musculotendinous units in the neck. The spectrum of injury ranges from mild to moderate, with rupture being extremely rare. These account for approximately $50 \%$ of neck injuries in wrestling.

Both Torg [23] and Boockvar et al. [24] have studied cervical cord neurapraxia in athletes. Torg [23] found that $87 \%$ of the cases occurred in football and only $2 \%$ in wrestling. Boockvar et al. [24] found 13 children, ages $7-15$ years, with cervical cord neurapraxia. Two of them were wrestlers.

\section{Upper Extremity}

Upper extremity injuries are also commonplace in the sport of wrestling due to the heavy forces placed on this region and the extreme positions that can occur during wrestling $[5,13]$. Table 2 outlines that these injuries have been reported anywhere from 9.3 to $42 \%$ of all injuries. The shoulder had the highest proportion of injury, as high as $24 \%$ of total reported injuries. The upper arm had the lowest reported frequency of upper extremity injury ranging from 0.8 to $1.4 \%$.

Percentage of shoulder injuries has been reported in the range of $3.5-24 \%$ of wrestling injuries in the pediatric population, and occur second only to injuries occurring at the knee [7, 12]. A recent prospective study showed shoulder injuries to be the most common overall injury in a high school wrestling population, at $24 \%$ of the total injuries reported [7]. 
Several case series of ruptures of the pectoralis major have been reported. Bak et al. [25] reported on 87 athletes with pectoralis major ruptures, 10 of whom were wrestlers. Pavlik et al. [26] reported on 7 athletes, 4 of whom were wrestlers. All patients had successful surgical treatment. The final case reported by Berson [27] was also treated with early surgical repair. Other shoulder injuries occurring in wrestlers have been documented in a variety of case reports. Those include documented injuries to the suprascapular nerve, subscapularis tendon, sternoclavicular joint and avulsion fractures of the scapula and lesser tuberosity [28-32].

Elbow injuries are sustained less frequently than shoulder injuries but appear to be more severe. In the prospective and retrospective studies shown in table 2, elbow injuries accounted for $1.0-7.9 \%$ of all wrestling injuries. The most common elbow injury is the hyperextension abduction sprain affecting the ulnar collateral ligament and the anterior capsule. Younger wrestlers appear to be susceptible to various types of avulsion fractures about the elbow, including the olecranon and the medial humeral epicondyle [33-35].

Injuries to the hand are almost always minor. Fractures or dislocations occur uncommonly. As shown in table 2, hand and wrist injuries accounted for $1.2-11.2 \%$ of all injuries. The most common hand injuries are metacarpophalangeal sprains, proximal interphalangeal sprain, and thumb metacarpophalangeal ulnar collateral ligament sprain (gamekeeper's thumb).

Trunk and Spine

As shown in table 2, low back injuries have comprised from 1.2 to $18.6 \%$ of total wrestling injuries in prospective and retrospective studies. Estwanik et al. [16] also noted that $25 \%$ of the wrestlers in his study presenting with back pain had spondylolysis or spondylolisthesis; $58 \%$ of his patients were diagnosed with lumbar strain. Rossi and Dragoni [36] reviewed the radiographs of 3,132 athletes aged 15-27 who were evaluated for low back pain over a 26-year period. Wrestlers with back pain had a $29.8 \%$ prevalence of spondylolysis (17 of 67 wrestlers).

Injuries to the rib and chest comprise $4.1-16.1 \%$ of total injuries in prospective studies. Most of these injuries are contusions or costochondral sprains, but rib fractures are also common. Injuries to the rib cage can result from direct or indirect trauma.

Among the prospective and retrospective studies documented in table 2, abdominal injuries account for only $0.35-0.4 \%$ of the total number of injuries found in wrestling. Diamond [37] described abdominal wall contusions as the most common injury, characterized by tenderness only in the area affected with no referred pain. 
Table 3. Knee injuries

\begin{tabular}{|c|c|c|c|c|c|}
\hline Study & $\begin{array}{l}\text { Study } \\
\text { design }\end{array}$ & $\begin{array}{l}\text { Injuries/ } \\
\text { total }(\%)\end{array}$ & $\begin{array}{l}\text { Significant } \\
\text { injuries/ } \\
\text { total }(\%)\end{array}$ & $\begin{array}{l}\text { Sprains } \\
\text { ( } \% \text { of total) }\end{array}$ & $\begin{array}{l}\text { Lateral meniscus/ } \\
\text { medial meniscus } \\
\text { (ratio) }\end{array}$ \\
\hline Lorish et al. [5] & $\mathrm{P}$ & $17 / 221(7.6)$ & & & \\
\hline $\begin{array}{l}\text { Requa and } \\
\text { Garrick [13] }\end{array}$ & $\mathrm{P}$ & $33 / 176(18.7)$ & & & \\
\hline $\begin{array}{l}\text { Powell and } \\
\text { Barber-Foss [14] }\end{array}$ & $\mathrm{P}$ & $430 / 2,910(14.8)$ & & & \\
\hline $\begin{array}{l}\text { Pasque and } \\
\text { Hewett [7] }\end{array}$ & $\mathrm{P}$ & $\begin{array}{l}38 / 219(17) \\
\text { Range } 7.6-18.7 \%\end{array}$ & & & \\
\hline $\begin{array}{l}\text { Estwanik et al. } \\
{[16]}\end{array}$ & & $256 / 666(38.4)$ & & $77(30)$ & $41 / 48(.46)$ \\
\hline Lok and & & $9 / 31(29)$ & & & \\
\hline Yuceturk [15] & & Range $29-38.4 \%$ & & & \\
\hline
\end{tabular}

\section{Lower Extremity}

A summary of studies reporting on the frequency of knee injures is shown in table $3[5,7,13-16]$. In prospective studies, knee injuries range from 7.6 to $18.7 \%$ of all wrestling injuries. In the only study with the percentage of knee injuries below 10\%, Lorish et al. [5] described injuries in tournaments to wrestlers aged 616 years. A liberal injury definition was used that required only that medical attention be sought. A study of high school wrestlers showed that knee injuries were the most common season-ending injuries, and represented $44 \%$ of the total [7].

Common knee injuries include prepatellar bursitis, medial and lateral collateral ligament sprains, and medial and lateral meniscus tears. The most common knee injuries are sprains, which constitute $30-65 \%$ of the total number of knee injuries. Meniscal injuries are also common, with a relatively high proportion of lateral to medial meniscus tears. In the two studies that broke this down, lateral meniscus injuries represented $46 \%$ of the total number of meniscal injuries [16], and there were $45 \%$ lateral versus medial meniscectomy in a study of 56 meniscectomies in wrestlers [38].

Mysnyk et al. [10] documented 28 cases of prepatellar bursitis, representing $21 \%$ of all knee injuries. Of the bursitis cases $50 \%$ were recurrent injuries. Eight cases of septic bursitis were reported. Anterior cruciate ligament injuries were noted in 14 of 256 knee injuries in one study [16]. Stanish et al. [39] presented 2 cases of isolated posterior cruciate ligament rupture 
in Canadian National Team members. He described the mechanism being forced flexion and internal rotation, which occurs in several wrestling maneuvers.

In prospective studies, ankle injuries range from 3.2 to $9.7 \%$ of all wrestling injuries. Garrick [40] described the results of the first year of the Seattle High School injury study. Ankle injuries were $6 / 105$ (6\% of wrestling injuries in that portion of the study). The most common ankle injury is the lateral ligament sprain, which most often occurs during takedowns.

\section{Action or Activity}

Due to the many different situations encountered in any individual match, the exact mechanism of injury is not always easily identified. In most cases, the injuries are the result of a situation during a wrestling match and not due to a specific move. In addition, there is also wide variability in the reporting of offending maneuvers, thus making accurate determinations of injurious moves difficult at best [7].

Knowledge of when injuries are most likely to occur can be of great assistance in prevention methods and in organizing medical coverage for wrestling events. During their study on catastrophic high school wrestling injuries, Boden et al. [2] noted that the takedown was the most common activity occurring during catastrophic injury, and that the athlete was at a disadvantage $74 \%$ of the time. Pasque and Hewett [7] reported that most of the injuries in their studies occurred during takedown, but more specifically, when the athlete was at a disadvantage or in the defensive position. Hoffman and Powell [3] also cites the takedown as the most injurious action.

Strauss and Lanese [8] reported no difference between injury rates occurring during takedown and mat wrestling. Only Kersey and Rowan [9] reported that mat wrestling had a higher rate for injury (49\%) than takedown (24.5\%). This high rate of injuries during mat wrestling may be a reflection of the way in which injuries were reported in the study. Any instance in which an official halted a match was recorded as an injury.

The most common wrestling situation resulting in injury is the takedown position in which both wrestlers are in the standing position attempting to take the other down to the mat [7,13]. Most of these injuries occur in the defensive wrestler, since they are at the mercy of their opponents while trying to protect themselves as they are being taken down to the mat. The higher occurrence of injury in the takedown position is likely attributable to the high intensity, speed and forces involved when trying to take the opponent to the mat, especially in older athletes. There is also a higher likelihood of more time spent in this position due to the increasing emphasis on takedown moves for scoring points in all forms of wrestling [7]. 


\section{Chronometry}

Lorish et al. [5] was unable to calculate injury by match, but could determine an injury rate of 3\% for all wrestlers in the first period. Strauss and Lanese [8] reported the greatest number of injuries to be in the second period, not the third as they hypothesized. Pasque and Hewett [7] also reported a trend toward more injuries in the latter half of practice and during the second and third periods. This finding, however, was not statistically significant and therefore suggests that fatigue may not be a factor that increases risk of injury.

The overall pattern of training during the season may also affect injury rates. Patacsil [11] found that the majority of injuries, 123/200 (61.5\%), occurred in the first half of the season. Early in this season, more wrestlers are vying for starting roles and more are preparing for their first tournaments of the year. Wrestle-offs for spots on the team also occur during the first month of the season. Intensity may subsequently diminish because many wrestlers resolve themselves to nonstarting status and do not push themselves as hard. Early season tournaments may present an increased risk. Wrestlers' conditioning has not reached optimum levels and with multiple matches in a day, it is easy for a minor injury to evolve into a significant injury.

\section{Injury Severity}

\section{Injury Type}

Common general injury categories in pediatric wrestling include muscle strains, joint sprains, concussions, contusions and abrasions or lacerations. Muscle strains usually involve the shoulder or lower back. Joint sprains usually involve the ankle, knee or hand/wrist regions. Contusions typically involve the knee, chest and head. Abrasions or lacerations almost always involve the face area [7], but can also occur on the extremities.

\section{Head/Spine/Trunk}

Injuries to the head from wrestling, mainly concussions, occur by head-to-head or head-to-knee collisions during takedowns. Concussions are also produced by contact with the wrestling mat or the floor surrounding the wrestling mat area. The head-injured athlete should always be assumed to have sustained neck trauma as well, and further evaluation, management, and possible transportation should take place.

Acute facial trauma can be a common problem in any age group [17]. Most injuries involve nose bleeds or minor abrasions that require only local wound care. Facial lacerations can occur, and usually involve the periorbital region, mouth or chin region. Nosebleeds occur commonly due to a combination 
of trauma and drying of the nasal mucosa secondary to relative dehydration and generally low ambient-relative humidity in gyms and wrestling rooms. Most occur in the anterior chamber of the nose and arise from the lower portion of the septum $[4,41]$. Periorbital contusions causing severe edema swelling or subcutaneous hematomas can occur from a blunt blow, such as a head-to-head collision, and can result in blockage of vision.

Auricular hematoma or 'wrestler's ear' is usually a chronic problem due to repetitive friction injuries to the external ear from improper headgear or from not wearing any at all $[16,42]$. Dental injuries are another area where occasional injuries occur with severe blows to the face, especially in young wrestlers with braces [4]. Most involve only oral lacerations, but some can include tooth fractures or avulsions.

Spine injuries have been reported in some studies, with most involving the cervical [9] or lumbar areas [5, 13]. Noncatastrophic injuries to the neck are common despite generally superior neck muscle strength among wrestlers. A common mechanism for a neck injury occurs during a takedown when the wrestler drives into his opponent with his neck, hyperextending it while 'shooting'. This can cause sprains, strains, and neurological trauma such as stingers. In rare instances, severe fractures, subluxations or dislocations of the spine occur and can result in devastating catastrophic injuries [2, 6].

Most commonly due to traumatic stretching or pinching of the brachial plexus or nerve roots, stingers occur almost exclusively during takedowns. The most common mechanism is forced hyperextension with ipsilateral flexion or extension when a wrestler 'shoots' a takedown with his neck bulled, striking his opponent's chest or thigh with his forehead. Vaccaro et al. [43] documented three different mechanisms for stingers: the compression mechanism, a stretch mechanism which occurs when the head and neck are displaced to the contralateral side of the shoulder and the plexus is stretched, and a direct mechanism when a direct blow is received to the posterior triangle of the neck under which lies the brachial plexus.

Lower back injuries in wrestling commonly take place during takedowns. While sparring for position, wrestlers push against each other with the lumbar spine in mild hyperextension. This extension, coupled with twisting, results in injuries. Extension against resistance, as in lifting an opponent off the mat, and hyperflexion, as in rolling, are also mechanisms that account for low back sprain or strain.

\section{Upper Extremity}

Upper extremity injuries are also common in wrestling due to the heavy forces placed on this region and the extreme joint positions that can occur during live wrestling [5, 13]. Most of these injuries are self-limiting such as rotator 
cuff strains and contusions, but many result in significant lost time, such as acromioclavicular separations and glenohumeral subluxations or dislocations. A common mechanism for injuring the shoulder occurs when being thrown to the mat from a standing position. The wrestler may attempt to brace his fall with his extended arm, imparting force to the shoulder girdle. However, if he is unable to extend his arm, the fall may be taken directly on the shoulder.

\section{Lower Extremity}

The lower extremity has classically been held as the most commonly injured area in wrestling. The knee is usually the main area of injury [16], with the ankle a close second [8]. The medial and lateral collateral ligaments are at risk due to the potential for varus, valgus and rotational stresses. Effusion, if present, is usually indicative of a meniscal or articular cartilage injury [38]. Meniscus injuries occur most commonly via a twisting injury to a weight-bearing extremity. If a severe injury occurs with rapid effusion and pain, this usually indicates a more severe injury such as an anterior cruciate ligament tear or a patella dislocation. These injuries are usually season ending and often require surgical intervention. Prepatellar bursitis is another common type of knee injury, and is fairly unique to wrestling $[10,16]$.

The most common ankle injury is usually the lateral ligament complex sprain from an inversion injury, with the occasional distal fibula fracture occurring with more severe injuries. High ankle sprains can also occur and are usually due to forced external rotation injuries to the ankle-foot region. These are more severe, and can result in significant time lost.

Foot injuries are fairly rare in wrestling, especially in the younger athletes. Occasional mid-foot sprains occur due to severe twisting injuries to this region. First metatarsal-phalangeal joint injuries equivalent to a football 'turf-toe' injury can occur due to repetitive hyperextension injuries to the first ray region.

Skin

Skin infections continue to be a problem in the sport of wrestling. Most skin infections are caused by a fungus ('ringworm') or the herpes virus and occasionally involve staphylococcus or streptococcus bacterial infections. The location of infection is usually in areas of high contact with other wrestlers such as the head and neck region or the upper extremity [44, 45]. Immediate proper identification and isolation of infected wrestlers prevents outbreaks among teams or tournament participants [46, 47].

\section{Catastrophic Injury}

Catastrophic injuries can occur in wrestling [2,6]. Most catastrophic injuries involve severe rotational or axial blows to the cervical and head region that can result in fractures or dislocations with or without head trauma. 
The reports of these types of injuries are summarized in table 4 [36, 48-66]. Various case reports have appeared in the literature describing catastrophic injuries to other anatomical locations, and are also summarized in the table.

Mueller and Cantu [48] published an annual report from the National Center for Catastrophic Sports Injury Research (NCCSIR). Data for this ongoing study were obtained from clipping services, individuals, and from the National Federation of State High School Associations. Mueller et al. [48] described 46 catastrophic high school injuries, 2 of which were fatal, and one catastrophic college injury. The rate of direct catastrophic injury in high school was 0.97 per 100,000 wrestlers and 0.72 per 100,000 wrestlers for college competition. Mueller et al. also documented indirect fatalities over that 20 -year period, 14 in high school and 3 in college.

The studies by Laudermilk [49] and Boden et al. [2] analyzed NCCSIR data specific to wrestling. Laudermilk [49] reviewed 1982-87 data from the NCCSIR. Fifty percent of the 24 injuries involved the cervical spine, spinal cord or head. Other problems were cardiac arrhythmia, cardiomyopathy, respiratory arrest, pulmonary embolism, and unspecified cardiac disease. Forty-two percent of the injuries occurred during takedown and $71 \%$ occurred during matches. Boden et al. [2] reviewed the NCCSIR data from 1981 to 1999 . He documented 35 cases of catastrophic injuries, 34 among high school wrestlers and one among college wrestlers. Of the 35 injuries, 17 were classified as nonfatal, 17 serious, and one fatal. The rate of catastrophic injuries was about one per 100,000 participants. Of the 27 cervical spine injuries, 15 resulted in permanent disability, and 12 achieved full recovery. There were 4 cases of transient quadriplegia, 3 severe head injuries, one herniated disk, and one death. They defined the at risk settings: the wrestler defending on a takedown and match competition as opposed to practice.

Clarke [50] sent surveys to state high school associations and to individual colleges, defining a catastrophic injury as one causing permanent paralysis or death. From 1973 to 1975,8 injuries were found, all at the high school level. All resulted in permanent spinal cord injury, none in death. In 1989, Bailes and Maroon [67] reported on cervical spine injuries in athletes. Four percent of the total admissions to their spinal cord unit were related to sports injury.

In 1991, Bailes et al. [1] described a series of 3,200 spinal cord injuries at two centers over a 12-year period from 1975 to 1987. Two percent of these admissions were sports-related. 45 of the injuries were permanent. There were 13 injuries due to wrestling. Of these, 10 were spinal cord injuries, and 3 were fractures/subluxations without neurological injury. Five of the cervical cord injuries were permanent and 5 achieved a full recovery. Several other spinal cord injuries have been reported and are also summarized in Table 4 . A very low incidence of major head and spine trauma has been documented in children, but the incidence increased in the 15-18-year-old group [18]. 
Table 4. Catastrophic injuries

\begin{tabular}{lllllll}
\hline Study Level & $\begin{array}{l}\text { Study } \\
\text { design }\end{array}$ & $\begin{array}{l}\text { Data } \\
\text { collection } \\
\text { methods }\end{array}$ & Duration & $\begin{array}{l}\text { Number of } \\
\text { injuries }\end{array}$ & Rate & Condition \\
\hline
\end{tabular}

\begin{tabular}{|c|c|c|c|c|c|c|c|}
\hline $\begin{array}{l}\text { Mueller/ } \\
\text { NCCSIR [48] }\end{array}$ & $\mathrm{HS}, \mathrm{C}$ & $\mathrm{R}$ & Q & $\begin{array}{l}20 \text { years } \\
(1982-2002)\end{array}$ & $\begin{array}{l}46 \text { HS ( } 2 \text { fatal, } \\
28 \text { nonfatal, } \\
16 \text { serious }), \\
1 \text { C ( } 1 \text { nonfatal })\end{array}$ & $\begin{array}{l}\text { HS } \\
0.97 / 100,000 \\
\text { wrestlers, } \\
\text { C 0.72/100,000 } \\
\text { wrestlers }\end{array}$ & \\
\hline $\begin{array}{l}\text { Mueller/ } \\
\text { NCCSIR [48] }\end{array}$ & $\mathrm{HS}, \mathrm{C}$ & $\mathrm{R}$ & Q & $\begin{array}{l}20 \text { years } \\
(1982-2002)\end{array}$ & $\begin{array}{l}\text { indirect }-14 \\
\text { HS ( } 14 \text { fatal), } \\
3 \text { college } \\
\text { ( } 3 \text { fatal) }\end{array}$ & $\begin{array}{l}\text { HS } \\
0.30 / 100,000 \\
\text { wrestlers, } \\
\text { C 2.16/100,000 } \\
\text { wrestlers }\end{array}$ & $\begin{array}{l}\mathrm{C} \text { dehydration/weight- } \\
\text { loss related: hyperthermia, } \\
\text { rhabdomyolysis }\end{array}$ \\
\hline $\begin{array}{l}\text { Boden et al. } \\
{[2]^{\mathrm{b}}}\end{array}$ & $\mathrm{HS}, \mathrm{C}$ & $\mathrm{R}$ & Q & $\begin{array}{l}19 \text { years } \\
(1981-1999)\end{array}$ & $\begin{array}{l}35 \text { ( } 1 \text { fatal, } \\
17 \text { nonfatal, } \\
17 \text { serious) }\end{array}$ & & $\begin{array}{l}27 \mathrm{SCI} \text { ( } 15 \text { permanent, } \\
12 \text { full recovery), } 4 \mathrm{CCN} \text {, } \\
3 \text { head, } 1 \mathrm{HNP}\end{array}$ \\
\hline $\begin{array}{l}\text { Laudermilk } \\
{[49]^{\mathrm{b}}}\end{array}$ & JHS, HS & $\mathrm{R}$ & Q & $\begin{array}{l}5 \text { years } \\
(1982-87)\end{array}$ & $\begin{array}{l}24 \text { ( } 8 \text { serious, } \\
6 \text { nonfatal, } \\
10 \text { fatal })\end{array}$ & $\begin{array}{l}1.07 / 100,000 \\
\text { wrestlers }\end{array}$ & $\begin{array}{l}12 \mathrm{cervical} / \text { head, } \\
12 \mathrm{cardiac} / \mathrm{systemic}\end{array}$ \\
\hline $\begin{array}{l}\text { Bailes et al. } \\
{[1]}\end{array}$ & & $\mathrm{CS}$ & & & $\begin{array}{l}13 \text { (10 SCI, } \\
3 \text { fracture/ } \\
\text { subluxation) }\end{array}$ & & $\begin{array}{l}5 \mathrm{SCI} \text { permanent, } \\
5 \mathrm{SCI} \text { full recovery }\end{array}$ \\
\hline Clarke [50] & $\mathrm{HS}, \mathrm{C}$ & $\mathrm{R}$ & Q & 3 years & $8 \mathrm{HS}, 0 \mathrm{C}$ & & 8 permanent $\mathrm{SCI}^{\mathrm{a}}$ \\
\hline Kewalramani & & $\mathrm{R}$ & I & & 5 & & $5 \mathrm{SCI}$ (5 permanent) \\
\hline
\end{tabular}




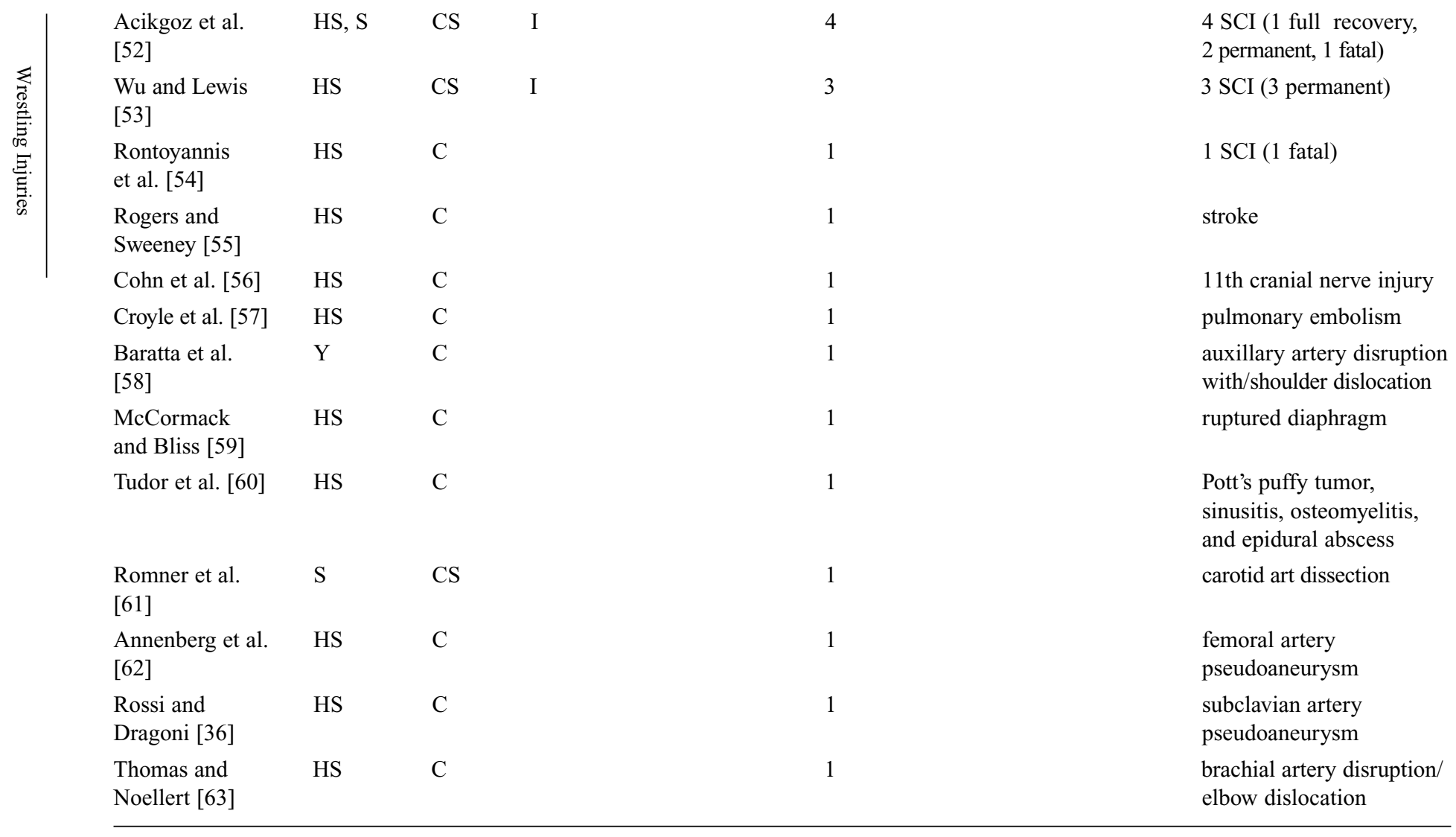


Table 4. (continued)

\begin{tabular}{|c|c|c|c|c|c|c|c|}
\hline Study & Level & $\begin{array}{l}\text { Study } \\
\text { design }\end{array}$ & $\begin{array}{l}\text { Data } \\
\text { collection } \\
\text { methods }\end{array}$ & Duration & $\begin{array}{l}\text { Number of } \\
\text { injuries }\end{array}$ & Rate & Condition \\
\hline $\begin{array}{l}\text { Schaefer and } \\
\text { Voight [64] }\end{array}$ & HS & $\mathrm{C}$ & & & 1 & & $\begin{array}{l}\text { brachial artery disruption/ } \\
\text { elbow dislocation }\end{array}$ \\
\hline $\begin{array}{l}\text { Pearsall and } \\
\text { Russell [65] }\end{array}$ & HS & $\mathrm{C}$ & & & 1 & & $\begin{array}{l}\text { long thoracic nerve injury } \\
\text { with/clavicle fracture and } \\
\text { spinal cord subluxation }\end{array}$ \\
\hline $\begin{array}{l}\text { Medler and } \\
\text { McQueen [66] }\end{array}$ & HS & $\mathrm{C}$ & & & 1 & & $\begin{array}{l}\text { subclavian vein } \\
\text { thrombosis }\end{array}$ \\
\hline
\end{tabular}

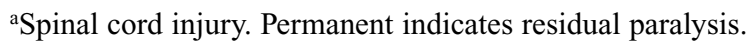

bDetailed analysis of NCCSIR data.

$\mathrm{HS}=$ High school; $\mathrm{S}=$ school; JHS = junior high school; $\mathrm{C}=$ college; $\mathrm{CS}=$ case series; $\mathrm{Q}=$ questionnaire; $\mathrm{I}=$ interview; $\mathrm{SCI}=$ spinal cord injury; $\mathrm{CNN}=$ cervical cord neurapraxia; $\mathrm{HNP}=$ herniated nucleus pulposus 


\section{Injury Risk Factors}

\section{Exposure}

The risk of injury increases as exposure to injurious situations increases. Only one pediatric wrestling study actually examined injury rate with reference to exposure. Pasque and Hewett [7] considered one wrestler participating in one practice or match, in which he was exposed to the possibility of injury as the definition of athlete-exposure.

Many studies report on the incidence of injury occurring in practice and competition. Incidence rates are higher during competition, but more injuries occurred during practice because significantly more time is spent in practice. Pasque and Hewett [7] reported that $63 \%$ of their injuries occurred in practice, while only $37 \%$ of the injuries occurred during competition. Matches lasted 6 minutes for a total exposure rate of 8,885 . When injuries were expressed in terms of exposure, a rate of 5 injuries per 1,000 practice-exposures as compared to 9 per 1,000 match-exposures occurred.

Boden et al. [2] reported a significantly greater number of catastrophic injuries occurring during match competition (80\%). This study further reported that approximately $86 \%$ of the catastrophic injuries that occurred during practice happened during live wrestling.

Increasing the level of competition and the amount of time-spent wrestling will increase the exposure of a wrestler to injury. Strauss and Lanese [8] studied injury patterns occurring at a boys' tournament, one high school, and two college tournaments. The boys had the lowest injury rates, but also spent the shortest amount of time exposed to injury, with matches lasting only $3 \mathrm{~min}$. The high school matches lasted $6 \mathrm{~min}$, and the college matches lasted up to $8 \mathrm{~min}$.

Pasque and Hewett [7] studied injuries among high school wrestlers over the course of one season and reported that the injured wrestlers had significantly more years of wrestling experience. There was a trend toward more injuries occurring at the varsity level. Varsity wrestlers comprised $44 \%$ of the study, but accounted for $60 \%$ of the injuries. This may be the result of more aggressive wrestling at that level. Pasque and Hewett [7] also found a slightly higher rate of injury for those who wrestled year round, though not statistically significant.

\section{Training Methods/Conditioning}

Few data are published on training conditions as risk factors in wrestling, but anecdotal observations can be made. Inadequate supervision of a wrestling team, especially in younger athletes, may increase injury risk by lack of monitoring potentially dangerous situations and techniques, and the inability to discourage horseplay. Inadequate wrestling technique may also increase injury risk. Boden's [2] study on catastrophic injuries suggests that the inexperienced 
wrestlers may get themselves into precarious situations that predispose them to a serious injury. One of the injured wrestlers in that study had attempted to extricate himself out of a situation, but the full weight of his opponent landing on him caused serious neck injury. Another instance occurred when a wrestler was unable to protect himself from landing on his head while being slammed to the mat by his opponent. Boden et al. [2] also report that poor officiating, rules infractions, and dangerous moves were probably to blame for 11 of the 54 catastrophic injuries in that study.

Puggelli [68] made specific recommendations for wrestling coaches in regard to training factors. He emphasized careful drilling of steps in a technique, organization of practice so that all bodies move in generally the same direction and teaching moves commensurate with the physical capabilities of the athletes.

\section{Protective Equipment/Facilities}

In wrestling there is not much extraneous equipment, but what little there is may be a factor in sustaining injury. Headgear is mandated most for competitions, but there is otherwise very little gear worn in wrestling. Although the headgear does not always prevent injury, it does offer protection from serious auricular injury [69]. In Boden's [2] study, headgear played at least a small role in 2 athletes suffering a catastrophic injury when the strap got caught on the mat. Absence of headgear is a risk factor in sustaining auricular hematoma. If the headgear is not properly fitted, the sweat on a wrestler's head can cause the headgear to slide and result in a hematoma by abrading the external ear. The role of knee pads, shoes, and mouth guards have not been evaluated, but in other sports they have been effective in preventing injuries.

The wrestling mat is, by far, the largest piece of equipment used in wrestling. A mat in good condition is essential for aiding in the prevention of serious injuries. Placement of objects close to the mat must be carefully monitored and padded. Mysnyk's [10] study of prepatellar bursitis in college wrestlers showed a much higher incidence $(69 \%)$ in the off-season when compared to the regular season. The use of older, de-conditioned wrestling mats during the off-season is cited as the potential reason. If mats are in poor condition, their ability to absorb shock may deteriorate, and thus increase injury risk when wrestlers land on them. A second major item is cleanliness of the mats. Without daily disinfection, counts of microorganisms on the mat will theoretically increase, and hence increase the chance of transmission of dermatological infections from mat to wrestler. Unpadded walls, obstacles such as columns or bleachers, inadequate space, and extreme heat or humidity are obviously detrimental. Antonacci [70] recommended appropriate padding of walls and any objects near mats as well as appropriate ventilation and lighting and mat washing technique in his preventive program. 
Mouthguards are not a required piece of equipment for wrestling, as they are for other sports like American football and hockey, therefore their use is low. Kvittem et al. [4] studied orofacial injuries in high school and reported that about $70 \%$ of the wrestlers in that study sustained at least one injury. Utilization of mouthguards amongst wrestlers was only 5.6\%. In Lee-Knight's [20] study, no wrestler used a mouthguard. In another study by Diab et al. [71], 359 parents of children aged 7-18 years were surveyed about the mouthguard usage in a variety of sports. Only $29 \%$ of children wore mouthguards. Parents reported 206 instances of oral trauma. Eighty-eight percent of these injuries occurred without mouthguards and only $12 \%$ with mouthguards. Most injuries were contusions and lip lacerations, but 'chipped teeth' were also documented. Wrestlers cited several reasons for not wearing mouthguards. These included poor retention secondary to fit, discomfort, and interference with breathing or speech.

Persson and Kiliaridis [21] also examined dental injuries among wrestlers and found them to suffer more injuries than the controls. Considering that US football, ice hockey, and rugby players have seen a drastic decrease in dental injuries with mouthguard use, wrestlers would also likely see a decrease with its use.

\section{Dehydration and Weight Loss Methods}

Wrestlers often lose large amounts of weight in a short period of time. Fluctuations in weight may occur frequently throughout the season [72]. Studies of weight loss practices among high school and college wrestlers indicate that some $3-20 \%$ of the preseason body weight is lost prior to certification or competition. Most of this weight loss occurs on the final day or days before the official weigh-in, with the youngest and/or lightest team members, losing the highest percentage of their body weight.

The effects of acute and prolonged dehydration are significant reductions in blood plasma volume, performance, and muscular strength [73-77]. Aerobic performance is affected to a much larger degree than the anaerobic performance [78]. When fluid loss exceeds $2 \%$ of normal stable body weight, significant changes occur during submaximal work, which include elevated heart rate, reduced stroke volume, and lowered cardiac output. These changes in cardiovascular function are potentially dangerous especially in combination with an elevated core temperature, altered electrolyte balance, and possible renal changes [79]. Current rules call for weigh-in to take place within a maximum of one hour and a minimum of one-half hour before the scheduled start time of a dual meet. But, even when 5 hours is allowed between weigh-in and the match, time is not sufficient for restoration of electrolyte balance and replenishing muscle glycogen concentration [75, 79]. The practice of fluid deprivation has been discouraged by the American College of Sports Medicine [73]. 


\section{Suggestions for Injury Prevention}

\section{Equipment}

Wrestling is an aggressive contact sport, and will never be free from potential injury situations. However, by examining how injuries occur, we can gain insight into their prevention. Having adequate practice space for the wrestlers can lead to the avoidance of many injuries. Snook [22] recommends providing at least 100 square feet per wrestling pair whenever possible. Larger practice areas prevent pairs of wrestlers rolling into each other or other objects like walls.

Injuries due to direct blows, forces or falls will likely never be completely eliminated given the physical nature of the sport, but certain measures are helpful in decreasing injuries. High quality mats of proper material and thickness

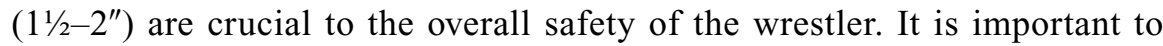
replace or recondition wrestling mats when they become worn. In addition, proper padding should be placed over any hard objects around the mat such as hard wood or concrete floors, walls or scoring tables.

Wearing properly fitted headgear for practice and competition is also recommended. Although wearing headgear is mandatory for most competitions, it is not a required piece of equipment for practice. Even though most coaches believe headgear to be effective in preventing serious auricular injury, many do not mandate its use for practices. It is recommended that headgear have a sufficient number of straps to fix the headgear firmly on the head and with deep enough earpieces so that there is no contact between the ear itself and the headgear. We often add a $1 / 4-1 / 2$ " thick high-density foam 'donut' around the earpiece to further increase its depth. Headgear is currently required during all matches. It is also recommended they be worn by all wrestlers at all practices.

Mouthguards have never been a standard piece of equipment used by wrestlers. Most wrestlers do not wear them due to poor fit or difficulty breathing. Use of well-fitted mouthguards during practice and competition may prevent irreversible dental injury.

\section{Coaching and Refereeing}

Many wrestlers are inexperienced, especially at the middle- and highschool levels, and thus close attention to proper technique is essential for a safe competition. Boden et al. [2] recommends that coaches teach wrestlers to keep their heads up when performing shooting or takedowns, to avoid axial compression or flexion of the spine leading to serious injury. This is already common practice among football coaches when teaching the tackling the technique. Better attention by wrestling officials to rules infractions and dangerous moves can also be crucial in preventing serious injury. 
Pasque and Hewett [7] suggest that limiting the amount of time spent practicing live wrestling may decrease the incidence of injuries occurring during practice. Wroble [80] recommends beginning practices earlier in the season, and delaying the onset of competition to allow for wrestlers to be better prepared for competition.

Referees must remain in control of the match at all times. A solid, aggressive wrestling match is a safe athletic event as long as the referee is able to control the tempo of the match and prevent volatile tempers from getting out of hand. The referee must know illegal or potentially dangerous moves, and how to anticipate them. This is especially important in preventing improper slams to the mat or other potentially injurious moves. Such moves must be anticipated and prevented when possible, and penalized heavily when they occur.

\section{Healthcare Team}

Having an appropriate healthcare system in place prior to the start of the season is important. The healthcare team should consist of a minimum of a team physician and an athletic trainer. Ideally, an athletic trainer should be present at all practices and competitions, and the team physician at all competitions. Prior to the start of the season, all athletes would undergo a preparticipation evaluation, including an orthopedic screening, to detect any potential preexisting conditions. Wroble [80] suggests outlining treatment protocols and having strict guidelines for return to competition following injury.

Preseason protocols should be established for handling emergency situations during both practices and matches. A medical professional team and good communication with other healthcare professionals in the community is essential. It is necessary to discuss in advance with the local emergency response team how emergency situations will be handled. The medical team should enlist the services of a good dentist to assist with properly fitted mouthguards. Consulting with a local dermatologist may also be beneficial in handling some of the skin infections that will invariably occur.

\section{Training: Neck Injury Prevention}

Prevention of cervical spine injuries is facilitated by rules in amateur wrestling banning all holds that result in a wrestler being thrown to the mat out of control, particularly with spearing of the head and shoulders to the mat. Preseason history and physical examination are very important in screening for previous neck injuries in wrestlers. At the time of entry into high school or on starting in a new program, radiographs of the cervical spine should be obtained on those individuals who have either a positive history or physical examination for previous neck injury. Supervision by physicians and athletic trainers plays a 
great role in the reduction of neck injuries by establishing and enforcing strict return to action criteria.

Proper management of neck injuries should be a thoroughly familiar procedure to all medical personnel involved in the care of participants in high-risk sports and should include cardiopulmonary resuscitation as well as the acute care of head and neck injuries. The athletic trainer or the physician, or both, should make the coaching staff aware of the occurrence of minor head and neck injuries, and identify those athletes at high risk. Coaches should also be taught the importance of preseason neck strength conditioning and the signs and symptoms that are important to recognize in the injured wrestler. Strength, endurance, and flexibility are important elements in decreasing the frequency of neck injuries. A neck exercise program should therefore be incorporated into each team's conditioning program.

\section{Nutrition}

Fluid Replacement

Dehydration compromises an optimal performance and, if allowed to become severe, may be life-threatening. Thirst is an unreliable mechanism for determining hypohydration and fluid replacement, and athletes need to drink beyond satisfying thirst to rehydrate. Fluids should be taken before, during, and after exercise. While cold water appears to be a good fluid replacement, carbohydrateelectrolyte drinks can also be used effectively. When choosing a replacement fluid other than water, the most important factor to consider is promotion of rapid gastric emptying. Gastric emptying is affected by volume, temperature, and caloric content. Increasing fluid volume (up to $500 \mathrm{ml}$ ) and decreasing fluid temperature will increase gastric emptying. Increasing caloric content, the most important factor, decreases the gastric emptying rate. During exercise, however, dilute glucose solutions are emptied as quickly as water [81].

Athletes may find it uncomfortable to exercise after a large volume of fluid is consumed, and may therefore, prefer smaller amounts taken every $10-15 \mathrm{~min}$. Ideally, the drink should contain a glucose concentration of less than $2.5 \mathrm{~g} / 100 \mathrm{ml}$ $\mathrm{H}_{2} \mathrm{O}$, as higher level of glucose will significantly slow gastric emptying. Low levels of potassium and chloride ions should be present, but only become vital with extreme, prolonged exercise. All fluids should be taken cold.

\section{Energy Expenditure}

Weight control is an important aspect of wrestling, and wrestlers should understand the basic principles of nutrition. Information provided by a qualified professional can minimize misinformation. Calorie expenditure for wrestling is $14.2 \mathrm{kcal} / \mathrm{min}$ [82]. In general, daily calorie consumption should not fall below $2,000 \mathrm{kcal}$ to ensure that the nutrient needs of training and growth are met [83]. 
Wrestlers who are in negative calorie balance compromise their ability to synthesize glycogen. An adequate carbohydrate intake is essential for maintenance and repletion of glycogen stores, as carbohydrate for the wrestler contribute $55-60 \%$ of total caloric intake. While protein is essential for synthesis and repair of muscle, protein intake above $15 \%$ of total calories did not provide any added benefit [84]. Once protein needs are met, excess is either utilized for energy or converted to and stored as fat. Fat, though a valuable source of energy for athletic activity, should not exceed $20-30 \%$ of total calories.

\section{Suggestions for Further Research}

Future epidemiological research in youth wresting injuries is required. There are few studies currently available in the literature for the youth level in wrestling. There is not enough information regarding even the first stage of the epidemiology-etiology-prevention measures-epidemiology cycle that is necessary for beginning the attempt to reduce injuries in youth wrestling. There is a need for large-scale epidemiological studies of high school, middle school and club teams. Studies designed to address this specific research question must be attempted. However, there is a need for the larger, basic epidemiological studies of injuries in youth wrestling. The prevention of injuries in youth wrestling requires quality epidemiological research. The future is bright for epidemiological researchers interested in the study of youth wrestling.

\section{References}

1 Bailes JE, Hadley MN, Quigley MR, Sonntag VK, Cerullo LJ: Management of athletic injuries of the cervical spine and spinal cord. Neurosurgery 1991;29:491-497.

2 Boden BP, Lin W, Young M, Mueller FO: Catastrophic injuries in wrestlers. Am J Sports Med 2002;30:791-795.

3 Hoffman H, Powell J: Analysis of NATA high school injury registry data on wrestling. J Athl Train $1990 ; 25: 125$.

4 Kvittem B, Hardie NA, Roettger M,Conry J: Incidence of orofacial injuries in high school sports. J Public Health Dent 1998;58:288-293.

5 Lorish TR, Rizzo TD Jr, Ilstrup DM, Scott SG: Injuries in adolescent and preadolescent boys at two large wrestling tournaments. Am J Sports Med 1992;20:199-202.

6 Mueller FO, Cantu RC: Catastrophic injuries and fatalities in high school and college sports, fall 1982-spring 1988. Med Sci Sports Exerc 1990;22:737-741.

7 Pasque CB, Hewett TE: A prospective study of high school wrestling injuries. Am J Sports Med 2000;28:509-515.

8 Strauss RH, Lanese RR: Injuries among wrestlers in school and college tournaments. JAMA 1982;248:2016-2019.

9 Kersey RD, Rowan L: Injury account during the 1980 NCAA wrestling championships. Am J Sports Med 1983;11:147-151. 
10 Mysnyk MC, Wroble RR, Foster DT, Albright JP: Prepatellar bursitis in wrestlers. Am J Sports Med 1986;14:46-54.

11 Patacsil J: An analytical survey of the incidents of injuries sustained in intercollegiate and interscholastic wrestling. West Lafayette, Purdue University, 1955.

12 Konrad I: A study of wrestling injuries in high schools throughout seven midwest states. Michigan State College, 1951.

13 Requa R, Garrick J: Injuries in interscholastic wrestling. Physician Sportsmed 1981;9:44-51.

14 Powell JW, Barber-Foss KD: Traumatic brain injury in high school athletes. JAMA 1999;282: 958-963.

15 Lok V, Yuceturk G: Injuries of wrestling. J Sports Med 1974;2:324-328.

16 Estwanik JJ III, Bergfeld JA, Collins HR, et al: Injuries in interscholastic wrestling. Physician Sportsmed 1980;8:111-121.

17 Acksel J: A study of interscholastic wrestling injuries in the state of Missouri during the 1965-1966 season. Eastern Illinois University, 1966.

18 Bruce DA, Schut L, Sutton LN: Brain and cervical spine injuries occurring during organized sports activities in children and adolescents. Prim Care 1984;11:175-194.

19 Forrest LA, Schuller DE, Strauss RH: Management of orbital blow-out fractures. Case reports and discussion. Am J Sports Med 1989;17:217-220.

20 Lee-Knight C, Harrison E, Price C: Dental injuries at the 1989 Canada games: An epidemiological study. J Can Dent Assoc 1992;58:810-815.

21 Persson LG, Kiliaridis S: Dental injuries, temporomandibular disorders, and caries in wrestlers. Scand J Dent Res 1994;102:367-371.

22 Snook GA: A survey of wrestling injuries. Am J Sports Med 1980;8:450-453.

23 Torg J: Athletic injuries to the cervical spine and brachial plexus. Contemporary Orthopedics 1984;9:65.

24 Boockvar JA, Durham SR, Sun PP: Cervical spinal stenosis and sports-related cervical cord neurapraxia in children. Spine 2001;26:2709-2712; discussion 2713.

25 Bak K, Cameron EA, Henderson IJ: Rupture of the pectoralis major: A meta-analysis of 112 cases. Knee Surg Sports Traumatol Arthrosc 2000;8:113-119.

26 Pavlik A, Csepai D, Berkes I: Surgical treatment of pectoralis major rupture in athletes. Knee Surg Sports Traumatol Arthrosc 1998;6:129-133.

27 Berson BL: Surgical repair of pectoralis major rupture in an athlete. Case report of an unusual injury in a wrestler. Am J Sports Med 1979;7:348-351.

28 Ross GJ, Love MB: Isolated avulsion fracture of the lesser tuberosity of the humerus: Report of two cases. Radiology 1989;172:833-834.

29 Swischuk LE: Pain and decreased movement of left arm. Pediatr Emerg Care 1991;7:169-170.

30 Berry H, Kong K, Hudson AR, Moulton RJ: Isolated suprascapular nerve palsy: A review of nine cases. Can J Neurol Sci 1995;22(4):301-304.

31 Brindle TJ, Coen M: Scapular avulsion fracture of a high school wrestler. J Orthop Sports Phys Ther 1998;27:444-447.

32 Reddy R, Koneru B, Kenter K,Griffiths H: Radiologic case study. Subscapularis tendon tear. Orthopedics 2000;23:1150, 1223-1224.

33 Weiss C, Sawers R: Avulsion fracture of the olecranon process. Physician Sportsmed 1990;18: $110-116$.

34 Haugegaard M, Rasmussen S, Johannsen P: Avulsion fracture of the medial humerus epicondyle in young wrestlers. Scand J Med Sci Sports 1993;3:178-181.

35 Banas MP, Lewis RA: Nonunion of an olecranon epiphyseal plate stress fracture in an adolescent. Orthopedics 1995;18:1111-1112.

36 Rossi F, Dragoni S: Lumbar spondylolysis: Occurrence in competitive athletes. Updated achievements in a series of 390 cases. J Sports Med Phys Fitness 1990;30:450-452.

37 Diamond DL: Sports-related abdominal trauma. Clin Sports Med 1989;8:91-99.

38 Baker BE, Peckham AC, Pupparo F, Sanborn JC: Review of meniscal injury and associated sports. Am J Sports Med 1985;13:1-4.

39 Stanish WD, Rubinovich M, Armason T, Lapenskie G: Posterior cruciate ligament tears in wrestlers. Can J Appl Sport Sci 1986;11:173-177. 
40 Garrick J: Ankle injuries: Frequency and mechanism of injury. Athletic Training 1975;10:109-111.

41 Stevens H: Epistaxis in the athlete. Physician Sportsmed 1988;16:31-40.

42 Giffin C: Wrestler's Ear: Pathiophysiology and treatment. Ann Plast Surg 1992;28:131-139.

43 Vaccaro AR, Watkins B, Albert TJ, Pfaff WL, Klein GR, Silber JS: Cervical spine injuries in athletes: Current return-to-play criteria. Orthopedics 2001;24:699-703; quiz 704-705.

44 Becker TM, Kodsi R, Bailey P, Lee F, Levandowski R, Nahmias AJ: Grappling with herpes: Herpes gladiatorum. Am J Sports Med 1988;16:665-669.

45 Stiller MJ, Klein WP, Dorman RI, Rosenthal S: Tinea corporis gladiatorum: An epidemic of Trichophyton tonsurans in student wrestlers. J Am Acad Dermatol 1992;27:632-633.

46 Belongia E, Goodman J, Hollane E, Andres C, Homan S, Mahanit R, et al: An outbreak of herpes gladiatorum at a high-school wrestling camp. N Eng J Med 1991;325:906-910.

47 Beller M, Gessner BD: An outbreak of tinea corporis gladiatorum on a high school wrestling team. J Am Acad Dermatol 1994;31:197-201.

48 Mueller FO, Cantu RC: NCCSIR. National Center for Catastrophic Sports Injury Research; in 20th Annual Report, 2002.

49 Laudermilk J: Catastrophic injuries in junior high school and high school wrestling: A five season study. Chapel Hill, University of North Carolina, 1988.

50 Clarke K: A survey of sports related spinal cord injuries in schools and colleges, 1973-1975. J Safety Res 1977;9:140-146.

51 Kewalramani LS, Krauss JF: Cervical spine injuries resulting from collision sports. Paraplegia 1981;19:303-312.

52 Acikgoz B, Ozgen T, Erbengi A, Peker S, Bertan V, Saglam S: Wrestling causing paraplegia. Paraplegia 1990;28:265-268.

53 Wu W, Lewis R: Injuries of the cervical spine in high school wrestling. Surg Neurol 1985;9:353-355.

54 Rontoyannis GP, Pahtas G, Dinis D, Pournaras N: Sudden death of a young wrestler during competition. Int J Sports Med 1988;9:353-355.

55 Rogers L, Sweeney PJ: Stroke: A neurologic complication of wrestling. A case of brainstem stroke in a 17-year-old athlete. Am J Sports Med 1979;7:352-354.

56 Cohn BT, Brahms MA, Cohn M: Injury to the eleventh cranial nerve in a high school wrestler. Orthop Rev 1986;15:590-595.

57 Croyle PH, Place RA, Hilgenberg AD: Massive pulmonary embolism in a high school wrestler. JAMA 1979;241:827-828.

58 Baratta JB, Lim V, Mastromonaco E, Edillon EL: Axillary artery disruption secondary to anterior dislocation of the shoulder. J Trauma 1983;23:1009-1011.

59 McCormack DL, Bliss WR: Rupture of the diaphragm in a wrestling match. J Iowa Med Soc 1983;73:406-408.

60 Tudor RB, Carson JP, Pulliam MW, Hill A: Pott's puffy tumor, frontal sinusitis, frontal bone osteomyelitis, and epidural abscess secondary to a wrestling injury. Am J Sports Med 1981;9: 390-391.

61 Romner B, Sjoholm H, Brandt L: Transcranial Doppler sonography, angiography and SPECT measurements in traumatic carotid artery dissection. Acta Neurochir (Wien) 1994;126: 185-191.

62 Annenberg AJ, Vaccaro PS, Zuelzer WA: Traumatic pseudoaneurysm in a wrestler. Ann Vasc Surg 1990;4:69-71.

63 Thomas PJ, Noellert RC: Brachial artery disruption after closed posterior dislocation of the elbow. Am J Orthop 1995;24:558-560.

64 Schaefer WW, Voight SJ: Rupture of the brachial artery from closed posterior dislocation of the elbow in a wrestler. Orthopedics 1993;16:820-822.

65 Pearsall AW IV, Russell GV Jr: Ipsilateral clavicle fracture, sternoclavicular joint subluxation, and long thoracic nerve injury: An unusual constellation of injuries sustained during wrestling. Am J Sports Med 2000;28:904-908.

66 Medler RG, McQueen DA: Effort thrombosis in a young wrestler. A case report. J Bone Joint Surg Am 1993;75:1071-1073.

67 Bailes JE, Maroon JC: Management of cervical spine injuries in athletes. Clin Sports Med 1989;8:43-58. 
68 Puggelli J: Integrating freestyle and Grec-Roman techniques (part 2): Prevention of injuries. Scholastic Coach 1981;50:94.

69 Schuller D, Dankle S, Martin M, Strauss R: Auricular injury and the use of headgear in wrestlers. Arch Otolaryngol Head Neck Surg 1989;115:714-717.

70 Antonacci R: Safety and hygiene in wrestling. Athletic Journal 1956;37:28-30.

71 Diab N, Mourino AP: Parental attitudes toward mouthguards. Pediatr Dent 1997;19:455-460.

72 Tipton CM, Tcheng TK: Iowa wrestling study. Weight loss in high school students. JAMA 1970;214:1269-1274.

73 ACSM: American College of Sports Medicine position stand on weight loss in wrestlers. Med Sci Sports 1976;8:11-13.

74 Torranin C, Smith DP, Byrd RJ: The effect of acute thermal dehydration and rapid rehydration on isometric and isotonic endurance. J Sports Med Phys Fitness 1979;19:1-9.

75 Houston M, Marvin D, Green J: The affects of rapid weight loss on physiological functions in wrestlers. Phys Sports Med 1981;9:73.

76 Horswill C: Does rapid weight loss by dehydration adversely affect high-power performance? Sports Science Exchange 1993;3:30.

77 Fogelholm M: Effects of bodyweight reduction on sports performance. Sports Med 1994;18:249-267.

78 Horswill CA: Weight loss and weight cycling in amateur wrestlers: Implications for performance and resting metabolic rate. Int J Sport Nutr 1993;3:245-260.

79 Zambraski E, Tipton C, Tcheng T, Jordon H, Vailas A, Callahan A: Iowa wrestling study: Changes in the urinary profiles of wrestlers prior to and after competition. Med Sci Sports 1975;7:217-220.

80 Wroble R: Wrestling. Epidemiology of sports injuries. Champaign, Human Kinetics, 1996.

81 Murray R: The effects of consuming carbohydrate-electrolyte beverages on gastric emptying and fluid absorption during and following exercise. Sports Med 1987;4:322-351.

82 AAHPER: Nutrition for athletes. A handbook for coaches; in American Alliance for Health, Physical Education and Recreation. Washington DC, 1971.

83 Smith NJ: Weight control in the athlete. Clin Sports Med 1984;3:693-704.

84 Hecker A: Nutritonal conditioning for athletic competition. Clin Sports Med 1984;3:567-582.

Timothy E. Hewett, MD, PhD

Cincinnati Children's Hospital Medical Center

3333 Burnet Avenue; MLC 10001 Cincinnati, OH 45229-3039 (USA)

Tel. +1 513636 4366, Fax +1 513636 0516, E-Mail tim.hewett@chmcc.org 